\title{
O Programa de Aceleração do Crescimento (PAC): Pontos positivos e falhas de origem
}

Marcelo de Oliveira Passos*

O Programa de Aceleração do Crescimento (PAC) possui algumas falhas de origem e alguns pontos positivos. Inicialmente, em relação aos pontos positivos do PAC, podemos destacar os investimentos previstos em saneamento e habitação popular, que podem gerar impacto no aumento do bem-estar dos mais pobres. Todavia, é conveniente lembrar que o governo apenas induz investimentos privados nestes setores (por intermédio do aumento da disponibilidade de recursos ao setor privado, via financiamentos ou via desonerações tributárias).

A regionalização do planejamento de investimentos em infra-estrutura é um passo louvável do ponto de vista do planejamento estratégico de longo prazo no país, embora gere insatisfações naquelas regiões que se considerem merecedoras de mais recursos do PAC.

Os investimentos planejados na infra-estrutura são enfatizados no PAC, que prevê um fundo para custear obras de $\mathrm{R} \$ 5$ bilhões. A fonte destes recursos é o patrimônio líquido de R\$ 21 bilhões do FGTS. Caberá à Caixa Econômica Federal administrar o fundo e a um Conselho Gestor determinar quais projetos serão apoiados. O fiador que assumirá o risco de um eventual déficit do FGTS é o Tesouro. Ou seja, o plano prevê quem bancará o risco dos projetos insolventes. Além disso, o PAC deve priorizar mais de 100 projetos de investimentos em rodovias, hidrovias, ferrovias, portos, aeroportos, saneamento e recursos hídricos. Projetase a construção, a duplicação e a recuperação, ao longo de quatro anos, de 42 mil quilômetros de estradas, 2,5 mil quilômetros de ferrovias, além da ampliação e melhoria de 12 portos e 20 aeroportos. Há também para o setor elétrico a intenção de gerar 12.386 megawatts de energia elétrica e de construir 13,8 mil quilômetros de linhas de transmissão, além de projetos de construção de 4,5 mil quilômetros de gasodutos, instalação de 46 novas usinas de produção de biodiesel e de 77 usinas de etanol.

O plano prevê a possibilidade de os trabalhadores utilizarem no máximo $10 \%$ de seu saldo em aplicações neste fundo para infra-estrutura. O rendimento do FGTS é o da TR

\footnotetext{
* Doutorando do Programa de Pós-Graduação em Desenvolvimento Econômico da UFPR. Analista Econômico-Financeiro do Banco Regional de Desenvolvimento do Extremo Sul (BRDE). Professor do Departamento de Economia da UFPR. E-mail: marcelo.passos@brde.com.br.
} 
adicionada a 3\% ao ano. Assim, cabe ao governo fazer com que o rendimento do fundo supere o do FGTS, o que não deve ser muito difícil, dada a baixa rentabilidade deste último.

Outro mérito do plano é que ele possui a ambição de romper com o longo ciclo de hegemonia do pensamento ortodoxo na economia brasileira. Este ciclo iniciou-se na gestão de Pedro Malan como ministro da Fazenda nas duas gestões do ex-presidente Fernando Henrique Cardoso (1995-2002). Neste período os principais cargos econômicos do país foram destinados aos economistas da PUC e da Fundação Getúlio Vargas do Rio de Janeiro. O ciclo continuou na gestão de Antonio Palloci, durante o primeiro mandato do presidente Luís Inácio da Silva. Com efeito, o plano representa um avanço no sentido de recuperar a tradição de planejamento econômico no Brasil.

Quanto às falhas de origem do PAC, há uma suposição implícita de que a divulgação do plano - ação com forte efeito midiático - pode atrair o investimento privado. É sabido que a queda da taxa de juros estimula o crescimento do consumo e da renda, que precedem o crescimento do investimento. A dinâmica, na perspectiva keynesiana, é esta. Não havendo expectativas positivas acerca de uma elevação do PIB, a expansão do investimento simplesmente não ocorre. Portanto, as reformas tributária e da previdência aliadas aos cortes de juros básicos que já vêm ocorrendo, induziriam expectativas mais favoráveis dos agentes privados do que a divulgação do PAC. Os efeitos destas reformas sobre o consumo e o investimento seriam mais efetivos e duradouros.

Outro aspecto crítico é que o Brasil investe hoje cerca de $20 \%$ do PIB. Somente quando os agentes econômicos perceberem que existe real potencial de crescimento da renda e do consumo e a taxa de investimento subir para $25 \%$ do PIB poderemos manter taxas de crescimento mais favoráveis. Entretanto, para obter este crescimento com a manutenção de um nível tolerável de inflação, são necessárias as reformas estruturais. Infelizmente, as medidas do plano não configuraram uma reforma tributária infra-constitucional, tal como seria desejável. Não há também nenhuma medida importante no campo previdenciário. Neste sentido, e tendo em vista o momento político favorável para a aprovação de projetos pelo Congresso Nacional, as medidas do PAC foram tímidas.

Ademais, se as intenções do PAC não se coadunarem com a queda dos juros básicos e da taxa de câmbio apreciada, não haverá - supondo ausência de reformas - ambiente econômico adequado para induzir o setor privado a ampliar os seus investimentos. Deste modo, a manutenção de uma política monetária de cortes graduais da taxa básica de juros 
associada com uma política fiscal marcada por gastos públicos excessivos podem minar as melhores intenções do plano.

O PAC não contemplou medidas capazes de promover uma maior abertura da economia brasileira. Não há como falar em contenção da apreciação do real sem perceber a necessidade de promover uma economia mais aberta. Seria conveniente estipular algumas metas de redução de tarifas. Tais metas poderiam ser implementadas de forma negociada com outros países e blocos, de acordo com a obtenção de reciprocidades destes mesmos. Seria interessante, por exemplo, reduzir tarifas para produtos e serviços necessários para elevar a competitividade de alguns setores de nossa economia. O país carece de alguns bens e serviços que oneram nosso balanço de pagamentos (componentes eletrônicos, insumos químicos, tintas, vernizes, trigo e serviços de engenharia, por exemplo). Por outro lado, poderíamos obter reciprocidades que permitiriam ampliar mercados externos para os bens de setores que apresentaram dificuldades nos últimos anos, tais como o setor têxtil, de calçados e de brinquedos, além de beneficiar também as exportações dos bens que possuímos vantagem competitiva (carnes, soja, aviões, minérios, álcool, açúcar etc.).

Tal como foi afirmado, a idéia da utilização dos recursos do FGTS para financiar obras de infra-estrutura é defensável. Há, todavia, um obstáculo institucional a ser removido: o impedimento legal associado à alteração da lei do FGTS por medida provisória. Um sintoma das dificuldades que tal medida enfrentará é o fato de a Força Sindical, a Confederação Nacional dos Trabalhadores Metalúrgicos e a Confederação Geral dos Trabalhadores (CGT) terem entrado com uma Ação Direta de Inconstitucionalidade no Supremo Tribunal Federal contra a Medida Provisória que criou o plano.

É perceptível também que algumas medidas que constam do PAC, e que representam corte de tributos, já tinham sido adotadas. São os casos da Lei Geral das Micro e Pequenas Empresas (corte de $\mathrm{R} \$ 2,45$ bilhões), o reajuste de 4,50\% na tabela do Imposto de Renda (corte de R\$ 1,26 bilhão em 2007 e R\$ 2,5 bilhões em 2008), e a prorrogação da depreciação acelerada para novos investimentos (corte de R\$ 900 milhões em 2007 e 2008), bem como a prorrogação da cumulatividade do PIS e do Cofins para a construção civil (R\$ 600 milhões em 2007 e 2008).

Outro ponto discutível do plano é a suposição de que o crescimento da economia depende muito do investimento público. $\mathrm{Na}$ realidade, dos 504 bilhões de reais (soma dos investimentos até o ano de 2010), apenas 300 bilhões virão do setor público (sendo 68 bilhões do Orçamento Público e 232 bilhões das empresas estatais). Assim, apenas 13,5\% dos 
recursos do PAC virão do Orçamento federal, sendo 46\% provenientes das empresas estatais e 40,5\% do setor privado. Com efeito, $86,5 \%$ dos recursos do PAC já estavam programados pelas empresas do país. Sabe-se também que, no ano de 2006, o setor público investiu somente $2 \%$ do PIB. Coube ao setor privado o montante de investimentos de $18 \%$ do PIB $^{7}$.

No que tange à política de rendas, o PAC apresentou um acerto e um equívoco. Foi positiva a criação do teto de 1,5\% para a elevação real da folha de pagamentos por um ano (excluídos os acordos salariais definidos até o final de 2006). Esta medida poderá valer pelos próximos dez anos e é benéfica do ponto de vista do controle do dispêndio público. Ocorre que a política de correção de salários mínimos prevista pelo plano pode estimular, nos agentes privados, a busca pela reindexação de contratos, o que seria um risco considerável para a estabilidade de preços. A história econômica brasileira recente foi marcada pelo longo período de indexação dos contratos que se iniciou com a criação do mecanismo da correção monetária, em fins da década de sessenta. Somente durante a implementação do Plano Real a indexação dos contratos foi sendo gradativamente extinta. O processo, no entanto, foi muito custoso para o país e não há indícios claros de que ele não possa ser reativado mediante o estímulo de reajustes indexados do salário mínimo.

${ }^{7}$ Dados do IBGE. 